\title{
from I LOOK AT MY BODY AND SEE THE SOURCE OF MY SHAME SITE SPECIFIC
}

\author{
Mark Anthony Cayanan \\ Ateneo de Manila University/University of Adelaide \\ mcayanan@gmail.com
}

\begin{abstract}
About the Author
Mark Anthony Cayanan obtained an MFA from the University of Wisconsin in Madison and is a PhD candidate at the University of Adelaide. Among their publications are the poetry books Narcissus (Ateneo de Manila University Press, 2011) and Except you enthrall me (University of the Philippines Press, 2013); recent work has appeared or is forthcoming in Foglifter, Miracle Monocle, Crab Orchard Review, The Spectacle, and Lana Turner. A recipient of fellowships to Civitella Ranieri and Villa Sarkia, they teach at the Ateneo de Manila University.
\end{abstract}




\section{As Aschenbach}

This isn't about how, whatever it is, sour and stale, it pushes against the shut mouth of self-refusal. Something that ought to happen keeps never happening, mornings happen, and rain tries the window, through the window is a room of windows, the room, when it moves, moves like a chain-link fence, the hour is dead, and the body, which maintains that its decay acquires the value of knowledge, nevertheless concedes to the details of its life. But quietly. In truth, when life happens, it happens in the fourth person. In truth, no warning shot was fired, the walls of corrugated metal have bullet holes through which the future has escaped, and when asked about him, she takes his young face out of a cardboard box and reconstitutes her rage. The fourth person permits one to sentimentalize the pain of others without the shamelessness of cooptation. The body must find another body, sometimes this body is its own. From there, the body hopes to resist the story it inexorably becomes, because the body is the joke that needs to be explained, let the needing wait. 


\section{Variations on the word 'pass'}

As when something despite itself gives in to another. Having survived bullets from the first attempt, his luck runs out once they brandish the cleavers. They stash the verdigris-covered coins with unreadable characters in the town hall basement so they can turn the museum into a fast food joint. Or when out of a flute glass, a dust jacket, and the hangover he hasn't slept off, he handcrafts a new stiletto. When a dog barks, the dog barks ominously.

As when he gets off a jeep and runs across the deceptively unnavigable parking lot to reach the emergency room, and he trips, and when, between one unrehearsed emotion and another, there lies a third, which, were he to detect it, would ruin the narrative. Following his precedent, his two brothers. Once it hurts too much, they scrape a layer off their eyes with fingernail clippings. Blood pools on their palms as they offer thanks to a god who must have supplied their uniqueness.

As when he steps past a threshold that by others could've been easily overcome but which he felt was worth keeping quiet for, lest failure bring about judgment or, worse, nonchalance. He finally opens his mouth to let them see how the wafer has turned into flesh. Muscle, teeth, praise. The sun dances around, their souls flung outward, someone's hand is on a lever. Upon seeing their bodies, the mother, older than her youngest by fifty years, counts the gashes.

As when the sky borrows the color of October, the smell of somber rooms hanging in the air. Their shadows trail along the roof as they check which of the orange tiles they could pry free with a hammer claw. The wind waits, as the wind does, as assailants do, they wear masks and fade into the night like sirens. Shirt too tight around his waist, he thinks of how beauty, once the most negligible thing about himself, is the one loss he's managed to invent great memories of. 
As when they prowl the unlit alleys like the petty criminals whose lives they've handled, they say there are those who live in the roots of trees. When it rains, they hang from the underside of leaves, and when something a little more substantial than a knowing look is exchanged between them. Days later she remembers the smell of shit on her son's body. A man who doesn't ask for permission goes blind the next day, an awful echoing noise that the audience overhears implying his future.

As when he turns his shirt inside out and looks to the sky for affirmation. A neighbor feeds his children prawn crackers while his mother talks to a journalist. The children are used to seeing her in tears and so don't turn their heads. They remove the cardboard and know it's him through the thorny heart on his forearm. She unrolls a high-school diploma, they preserve her grief in pictures. As when his life is on a list of casualties in a notebook, her sleeping head flattening the spring. This sinking city. 


\section{Wind and teeth}

The boat through green water enters a dead god's calcified breath. His gasp when he flicks on the light of his hard hat is a door for his body, which, moving, keeps constituting new frailties. The cave preserves the dark, scatters it in small rooms. Some doorless rooms remain unopened. Unlike the wind that nudges the boat farther inward, his body just another guest, he assumes his persistence is a kind of grace that allows him to make the inevitable

meaningful. The rowing takes over an hour, he overhears the winged murmurs of bats and grows tired of looking at stalactites with his mouth closed, the oars ask for an endurance he thinks he used to possess. Sensing his quiet, the guide tells him to turn off the light, and the dark makes them indistinguishable from the cave's secrets. He knows his disappeared body exists by his fear, only another god can force them open. The guide, who earns a living by eliciting awe out of these mysteries, stops at a bank that leads to another grotto. In his awe

he is prosaic, he examines the drawings on the wall, charcoaled by men who hid from the war. Their boredom crawls toward posterity, history is its own unyielding force, consumes them, here where time passes with no one to measure it, does time become fiction. When he takes stones and lays them flat on a rock, he turns them into eyes, nose, a sad mouth, a sharper tongue. Muddy light makeshifts the face. He washes his hands in the river, under the surface the cold leads to more chambers, some as beautiful as a young body. The guide takes him 
down a path where ladders resting between boulders are bridges. The body's route is reticence, legs trying to scramble nimbly past the no of inconsistent limestones. The body shifting between longing and anger, sometimes as in this body they are the same. The body clutches a rope and fights the current to get across the river. The guide, while waiting for the body to catch its breath, smokes a cigarette, a man without a government. The body knows what its frailties are useful for. Before the guide asks if they're ready to go deeper

already this body that wants to be wind and teeth, the body that wants to be noticed, has prepared its lie. Making do with a language neither of them owns, he enters the great void of his middle age expecting profound transformation. 


\title{
Wonders and terrors of the variegated earth
}

\begin{abstract}
While they play cards someone strums a few chords and they supply the plaintive voice, supply the baby screaming in a corner, the husband humming as he pees on a fence, the tourists memorializing the show with their phones. They use the word slums and make the evening more important. Like a continent whose weak spot is its vanity, they've put themselves in good humor by buying this city's flea-market linen. Too happy, their happiness the color of cholera, they tire too quickly of haggling with hawkers. A mock summer has set in and since the typhoon that will kill several of them is still half a sea away, they hop from one bus onto another, feet gray-black, hands smelling of onion and vinegar.
\end{abstract}

